\title{
ANALISIS KELONGSORAN PENGEMBANGAN RUAS JALAN BUJANGGA PINGGIRAN SUNGAI SEGAH KOTA TANJUNG REDEP KABUPATEN BERAU
}

\author{
Bagus Eko Prasetyo', Mansyur², Fahrudi Ahwan Ikhsan³, Andri Estining Sejati ${ }^{4}$ \\ 1, 2Program Studi Teknik Sipil, Universitas Sembilanbelas November Kolaka \\ Jl. Pemuda No. 399 Kolaka \\ ${ }^{4}$ Program Studi Pendidikan Geografi, Universitas Jember \\ Jember, Jawa Timur
}

4Program Studi Pendidikan Geografi, Universitas Sembilanbelas November Kolaka

Jl. Pemuda No. 399 Kolaka

Email corresponding: prasetyo.eko.bagus@gmail.com

\begin{tabular}{|c|c|c|}
\hline Dikirimkan: & Diterima: & Diterbitkan: \\
$15-03-2020$ & $21-06-2020$ & $27-07-2020$ \\
\hline
\end{tabular}

\begin{abstract}
This research discussed the effect of scouring on the stability of the slope on the Bujangga street STA $00+000$ sd STA 00+075. A landslide had occurred in the development of a road located on the Bujangga riverside. The road is the result of widening which was previously only 2 lanes with a width of $8 \mathrm{~m}$ to 4 lanes with a width of $20 \mathrm{~m}$. Landslides occured at STA OO+OOO up to STA $00+075$. At the STA the road experiences a landslide in the direction of the river to the elevation of the road surface down as deep as $\pm 2 m$. This research type is survey. Data was collected with documentation of post-landslide soil investigations, investigation of landslide conditions in the field, and sheet-pile slip simulation using the finite element method with helping the PLAXIS V.7.2 program. Data analysis with descriptive and back analysis to input soil parameters produces deformation and landslide mechanism that is relevant to actual conditions in the field. As a result of scouring of the river there is a reduction in passive pressure on the outside of the sheetpile which results in a decrease in the value of the safety factor of the road including other buildings such as settlements. This is indicated by the results of modeling and simulation above which gives the value of FS=1.2602 without scouring and FS=1.045 after scouring. The scouring of the river can be concluded that on a long-term scale the location is a landslide prone location.
\end{abstract}

Keywords: Landslide Analysis, Finite Element, Road Development, Riverside

\begin{abstract}
Abstrak
Penelitian ini membahas pengaruh scouring terhadap stabilitas lereng pada kelongsoran Jalan Bujangga STA 00+000 sd STA 00+075. Pernah terjadi kelongsoran pada pengembangan jalan yang berlokasi di pinggiran sungai Bujangga. Jalan tersebut merupakan hasil pelebaran yang sebelumnya hanya 2 lajur dengan lebar $8 \mathrm{~m}$ menjadi 4 lajur dengan lebar $20 \mathrm{~m}$. Kelongsoran terjadi pada STA 00+000 sampai dengan STA O0+075. Pada STA tersebut jalan mengalami kelongsoran ke arah sungai hingga elevasi permukaan jalan turun sedalam $\pm 2 m$. Penelitian ini berjenis survey. Data dikumpulkan dengan dokumentasi penyelidikan tanah pasca longsoran, investigasi kondisi longsoran di lapangan, dan simulasi kelongsoran sheetpile menggunakan metode elemen hingga dengan bantuan program PLAXIS V.7.2. Analisis data dengan deskriptif dan back analysis hingga parameter tanah input menghasilkan deformasi dan mekanisme kelongsoran yang relevan dengan kondisi actual di lapangan. Akibat dari scouring atau gerusan sungai terjadi pengurangan tekanan pasif pada sisi luar sheetpile yang berakibat penurunan nilai faktor keamanan dari jalan termasuk bangunan lain seperti pemukiman. Hal tersebut ditunjukkan oleh hasil pemodelan dan simulasi di atas yang memberikan nilai $F S=1.2602$ tanpa scouring dan FS=1.045 setelah adanya scouring. Adanya gerusan pada bibir sungai dapat disimpulkan bahwa dalam skala jangka panjang lokasi tersebut merupakan lokasi rawan bencana longsoran.
\end{abstract}

Kata Kunci: Analisis Longsoran, Elemen Hingga, Pengembangan Jalan, Pinggiran Sungai 


\section{PENDAHULUAN}

Jalan Bujangga merupakan jalan nasional yang terletak di kota Tanjung Redeb, Kabupaten Berau, Kalimantan Timur. Jalan ini berada di pinggiran sungai Segah yang sekaligus menjadi jalur utama aktivitas penduduk sekitar. Menurut (Saragih \& Simanungkalit, 2015) sungai menjadi tempat aktivitas dari 92\% penduduk di Kota Binjai, selain sebagai tempat tinggal juga untuk aktivitas mandi, cuci, kakus.

Sungai Segah merupakan sungai yang membelah kabupaten Berau. Sungai Segah sekaligus menjadi jalur transportasi kapal pengangkut batu bara menuju muara sungai. Menurut (Amaluddin et al., 2019) transportasi merupakan poin penting dalam pengembangan daerah termasuk pariwisata, kombinasi darat dan perairan seperti Wellington dan Picton di New Zealand dengan ferry merupakan contoh keberhasilan sektor transportasi.

Pada bulan mei tahun 2012 terjadi kelongsoran pada ruas jalan yang berlokasi di pinggiran sungai tersebut. Jalan merupakan hasil pelebaran yang sebelumnya hanya 2 lajur dengan lebar $8 \mathrm{~m}$ menjadi 4 lajur dengan lebar $20 \mathrm{~m}$. Pelebaran jalan ke arah pinggiran sungai dengan menggunakan sheetpile yang diperkuat dengan deadman angkur. Kelongsoran terjadi pada STA 00+000 sampai dengan STA 00+075. Tanah longsor menyebabkan banyak kerugian baik infrastruktur jalan, pemukiman, maupun aktivitas manusia seperti perkebunan. Menurut (Damanik et al., 2020) daerah aliran sungai (DAS) dalam kasus di DAS Padang mengalami resiko longsor yang berpotensi menyebabkan banjir.

Pada STA tersebut jalan mengalami kelongsoran ke arah sungai hingga elevasi permukaan jalan turun sedalam $\pm 2 \mathrm{~m}$. Hal ini tentu akan mempengaruhi aktivitas masyarakat di sekitar jalan dan sungai tersebut. Menurut (Pane, 2017) aktivitas masyarakat di sempadan sungai Padang salah satunya untuk tempat tinggal dengan segala resikonya.

Tujuan dari dilakukannya analisis ini ada dua. Pertama, untuk mengetahui faktor-faktor dan penyebab terjadinya kelongsoran pada ruas jalan Bujangga STA $00+000$ sd STA 00+075. Kedua, melakukan analisis dan pemodelan sheetpile pada daerah kelongsoran untuk mengetahui nilai stabilitasnya menggunakan metode elemen hingga.

\section{METODOLOGI PENELITIAN}

Penelitian ini berjenis survey. Lokasi penelitian di ruas Jalan Bujangga kota Tanjung Redeb, Kabupaten Berau, Kalimantan Timur. Metode pengumpulan data yang digunakan pada penelitian ini, pertama, mengumpulkan data-data sekunder hasil penyelidikan tanah pasca kelongsoran yang telah dilakukan oleh CV. Indotech Building Consultant sebanyak 2 (dua) titik boring dan 8 (delapan) titik sondir.

Kedua, melakukan investigasi kondisi kelongsoran di lapangan berupa pengukuran besar deformasi lateral, mekanisme keruntuhan sheetpile, besarnya penurunan tanah, pengukuran arus air sungai, serta jenis dan ukuran sheetpile dan deadman anchor yang digunakan. Ketiga, melakukan simulasi kelongsoran sheetpile menggunakan analisis metode elemen hingga dengan bantuan program plaxis menggunakan model konstitutif Mohr-Coulomb. Analisis data dengan deskriptif dan back analysis hingga parameter tanah input menghasilkan deformasi dan mekanisme kelongsoran yang relevan dengan kondisi aktual di lapangan.

\section{HASIL DAN PEMBAHASAN}

Kondisi topografi area jalan Bujangga pada STA 00+000 sampai dengan STA 00+075 merupakan jalan yang berada di pinggiran sungai dan pemukiman penduduk disisi lainnya. Perkembangan jalan menjadikan arus barang, jasa, dan aktivitas masyarakat dapat meningkat. Menurut (Siringoringo \& Lumbantoruan, 2015) peningkatan jalan aspal sebesar $4,43 \%$ per tahun dapat meningkatkan kesejahteraan masyarakat.

Hasil survey yang telah dilaksanakan didapatkan kedalaman sungai mencapai $-25 \mathrm{~m}$ dari permukaan sungai dan lebar sungai mencapai 200 m. Sungai ini juga mengalami kondisi pasang surut dikarenakan langsung bermuara ke laut. Interval dari kondisi surut dan pasang maksimum adalah $\pm 3 \mathrm{~m}$. Menurut (Susanti \& Khotimah, 2017) karakteristik sungai menentukan bagaimana strategi dalam beradaptasi dengan sungai tersebut, kasus pada pemahaman karakter sungai Putih menjadikan pemerintah dan masyarakat setempat tepat dalam pemanfaatan transportasi dan kesiapan bencana. Hasil survey tersebut disajikan dalam gambar 1. 


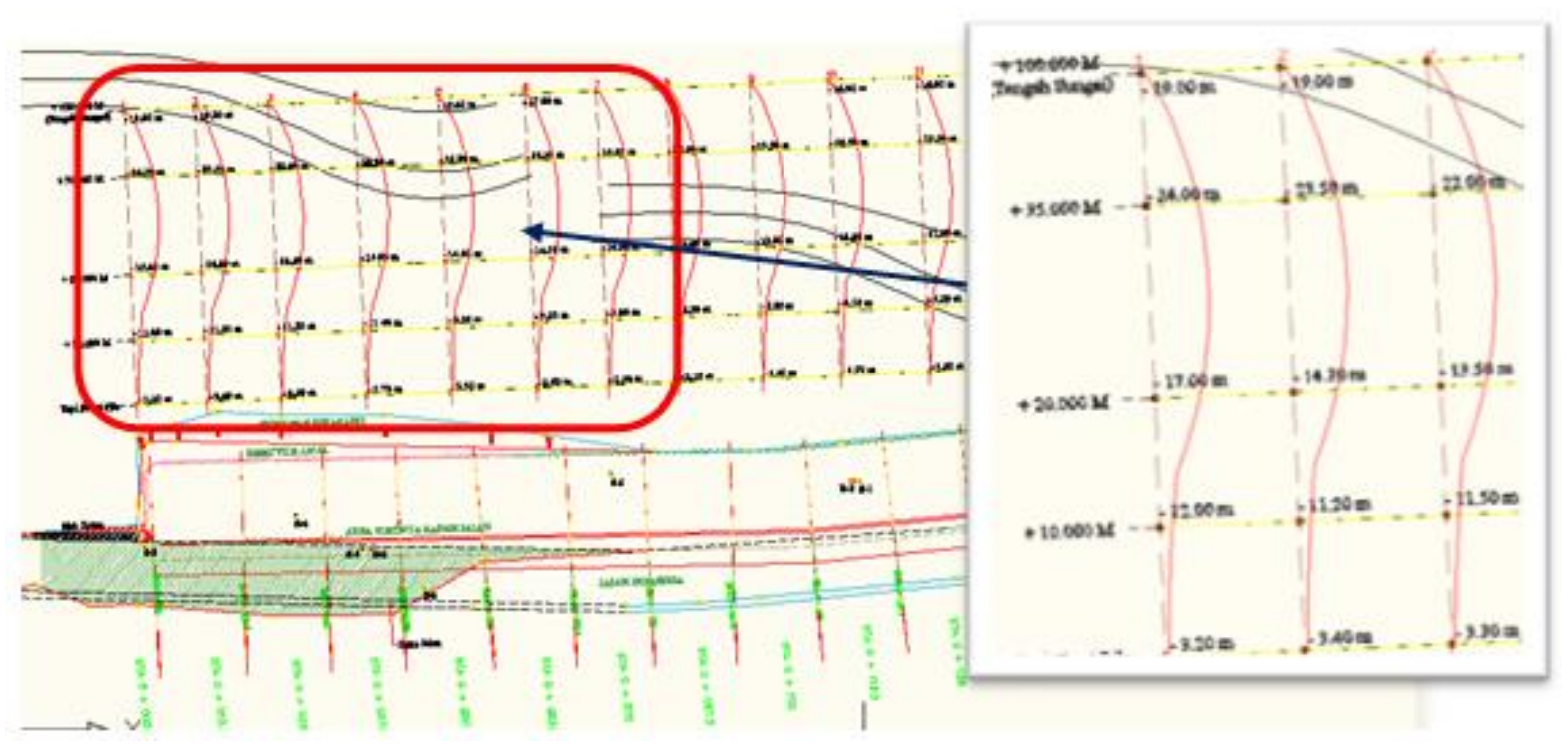

Gambar 1. Kontur Dasar Sungai di Lokasi Kelongsoran

Sungai Segah memiliki lebar sekitar 200 meter. Sungai ini merupakan akses bagi jalur transportasi penambangan batu bara dan langsung bermuara ke laut. Jenis kapal ponton bermuatan batu bara yang paling mendominasi lalu lintas disungai ini. Menurut (Siringoringo \& Lumbantoruan, 2015) perkembangan sarana trasportasi dapat meningkatkan arus barang yang mampu mendorong perekonomian masyarakat/daerah.

Sungai ini memiliki kecepatan aliran sebesar $\pm 0.5 \mathrm{~m} / \mathrm{s}$ pada permukaan dan memiliki arus bawah yang tinggi. Hal ini terlihat dari riak air yang membentuk cyclone pada permukaan sungai. Kondisi jenis tanah pada dasar dan tepi sungai merupakan tanah berlumpur dengan konsistensi soft clay yang ditunjukkan dari hasil analisa saringan dimana dominan butiranbutirannya lolos saringan no 200. Menurut (Damhuri et al., 2018) karakter tanah di tepian sungai adalah basah dan cocok untuk ditanami tanaman khususnya pertanian. Menurut (Nursalam et al., 2019) struktur tanah dapat dipengaruhi oleh keadaan geologi baik eksogen maupun endogen.

Berdasarkan keterangan warga setempat, dahulu daerah pinggiran sungai belum mencapai jalan yang sekarang ini, melainkan daratan yang ditempati oleh warga. Lambat laun pinggiran sungai semakin mendekat kedaratan akibat dari gerusan dan menyebabkan warga tidak bisa menempatinya karena terlalu berdekatan dengan sungai. Pada saat ini pinggiran sungai hanya tinggal beberapa meter saja dari jalan. Akibat dari lalu lintas air seperti kapal dan ponton, proses gerusan semakin cepat dikarenakan arus dan riak yang disebabkan kapal tersebut langsung melakukan kontak dengan tepi sungai. Menurut (Suparmini et al., 2014) masyarakat Badui banyak memanfaatkan tepian sungai sebagai pemukiman, tetapi mereka menjaga kelestarian baik hulu maupun hilir, sehingga tidak pernah terkena bencana.

Pasca terjadinya kelongsoran di ruas jalan Bujangga pada tahun 2012, telah dilakukan penyelidikan tanah berupa 2 titik bor dalam dan 8 titik sondir yang dikerjakan oleh CV. Indotech Building Consultant. Selain berupa data sondir dan NSPT, pada titik bor diambil sampel tak terganggu untuk diuji sifat fisik dan mekanisnya di laboratorium. Sebagai referensi dalam melakukan analisa kelongsoran yang terjadi pada lokasi antara STA 00+000 sampai dengan STA 00+150, maka digunakan data tanah yang diambil dari titik pengambilan sampel yang representatif yaitu dari $\mathrm{BH}-2$, dan S-5. Profil dan data parameter tanah sebagai berikut. 


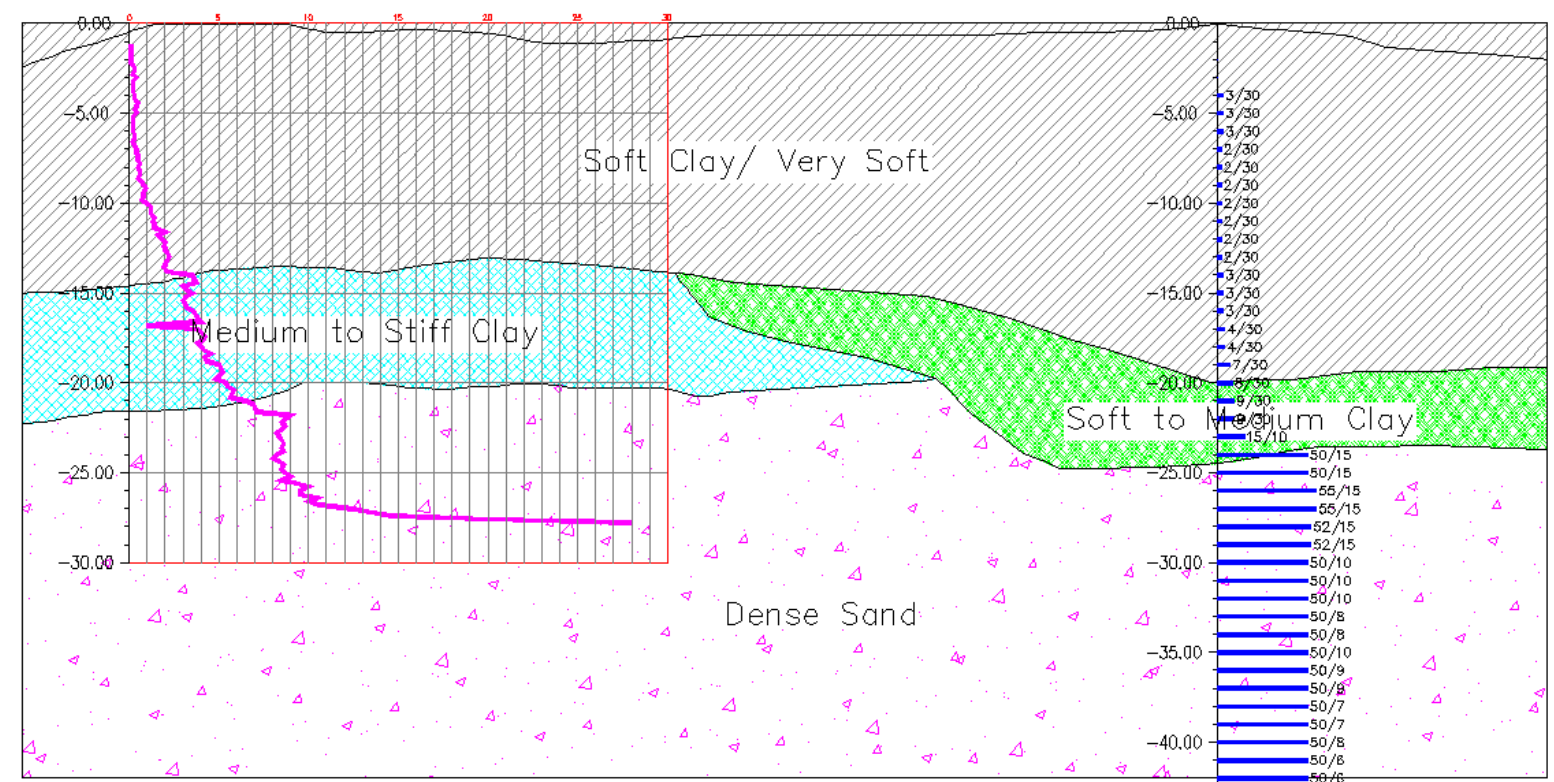

Gambar 2. Profil Lapisan Tanah Berdasarkan Data BH-2 dan S-5

Tabel 1. Data Parameter Tanah Berdasarkan Interpretasi Hasil Penyelidikan Tanah

\begin{tabular}{|c|c|c|c|c|c|c|c|c|}
\hline Kedalaman (m) & Konsistensi Tanah & $\begin{array}{c}\text { N-SPT } \\
\text { Reff }\end{array}$ & $\begin{array}{c}\gamma_{\mathrm{dry}} \\
(\mathrm{kN} / \mathrm{m} \\
3)\end{array}$ & $\begin{array}{c}\gamma_{\text {wet }} \\
(\mathrm{kN} / \mathrm{m} 3)\end{array}$ & $\begin{array}{c}\mathrm{Cu} \\
(\mathrm{kN} / \mathrm{m} 2 \\
)\end{array}$ & $v$ & $\phi$ & Es \\
\hline $0.00-1.50$ & Soft clay & - & 15 & 16 & 22 & 0.3 & & 5600 \\
\hline $1.50-2.50$ & Soft clay & - & 15 & 16 & 10 & 0.3 & & 1800 \\
\hline $2.50-4.75$ & Soft clay & 3 & 15 & 16 & 15 & 0.3 & & 3500 \\
\hline $4.75-7.00$ & Soft clay & 2 & 15 & 16 & 24 & 0.3 & & 4500 \\
\hline $7.00-9.00$ & Soft clay & 2 & 15 & 16 & 25 & 0.3 & & 5000 \\
\hline $9.00-13.00$ & Soft clay & 3 & 15 & 16 & 28 & 0.3 & & 5000 \\
\hline $13.00-16.00$ & Soft clay & 4 & 15 & 17 & 40 & 0.3 & & 8000 \\
\hline $16.00-24.00$ & Medium to stiff clay & 7 & 15 & 17 & 32 & 0.3 & & 7000 \\
\hline $24.00-26.00$ & Stiff clay & 9 & 15 & 17 & 70 & 0.3 & & 14000 \\
\hline $26.00-30.00$ & Dense Sand/Hard & $>40$ & 17 & 18 & - & 0.3 & 36 & 36000 \\
\hline
\end{tabular}

Hasil menunjukkan tanah dominan berbahan liat. Tiga komponen tanah baik itu pasir, liat, dan debu memiliki komposisi berbeda-beda. Unsur liat memiliki karakteristik mudah membentuk rekahan pada musim kemarau dan terlalu lengket pada musim penghujan. Menurut (Damhuri et al., 2018) karakteristik tanah yang berbahan dasar batuan karst mudah membentuk rekahan saat sedikit curah hujan. Menurut (Kasnar et al., 2020) sebaran jenis tanah berdasarkan infiltrasi perlu dilakukan untuk mengetahui kerawanan daerah terhadap multi bencana banjir dan longsor.

Metode elemen hingga adalah prosedur numerik untuk memecahkan masalah mekanika kontinum dengan ketelitian yang dapat diterima oleh rekayasawan. Suatu struktur kontinum dengan derajat kebebasan tak hingga dapat disederhanakan dengan diskretisasi kontinum ke dalam elemen-elemen yang lebih sederhana dengan derajat kebebasan tertentu.
Penyelesaian formulasi numerik pada metode elemen hingga yaitu dengan mula-mula menyelesaikan persamaan elemen-elemen lokal kemudian dirakit kedalam suatu sistem struktur sehingga menghasilkan solusi global dari sistem struktur tersebut.

Dalam algoritma analisisnya, tahap analisis pertama adalah perpindahan tambahan (additional displacement). Tahap ini diformulasikan dengan persamaan:

$$
\delta u=K^{-1} \delta P
$$

Analisis stabilitas lereng dilakukan dengan pemodelan menggunakan metode elemen hingga dengan bantuan program PLAXIS v.7.2. Model konstitutif tanah digambarkan dengan model tanah Mohr-Coulomb. Parameter tanah yang digunakan dalam analisis di tentukan berdasarkan referensi dari data Bor $\mathrm{BH}-2$ dan Sondir S-5 sesuai dengan lapisan dan kedalamannya. 


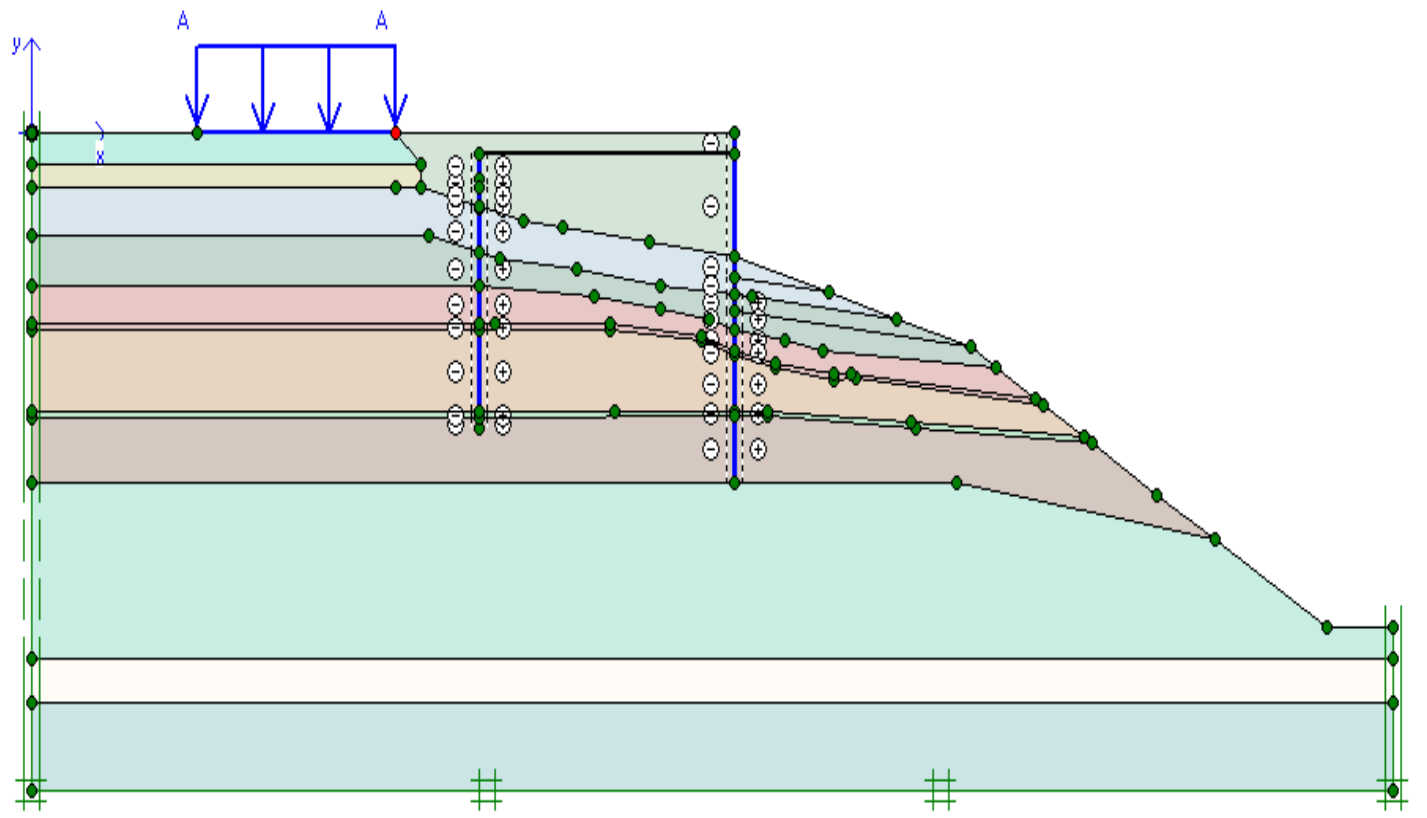

Gambar 3. Model 2D PLAXIS Sesuai Potongan Melintang

Model yang digunakan mengikuti topografi sesuai potongan melintang jalan dan stratifikasi lapisan tanah sesuai soil profile di atas. Berdasarkan data yang diperoleh dilapangan, pemasangan sheetpile pada ruas jalan tersebut tidak dilakukan secara simultan dan tidak dikerjakan pada tahun yang sama. Sheetpile yang terpasang pada lokasi yang mengalami longsor merupakan sheetpile yang telah dipasang sejak tahun 2010. Dari gambar 4 sampai 6 di bawah dapat diketahui bahwa posisi kelongsoran berada pada kelokan sungai dan juga berada pada sudut gerusan maksimum dikarenakan arah aliran dari hulu hampir tegak lurus terhadap posisi kelongsoran. Sehingga posisi tanah pada daerah pasif sheetpile telah berkurang akibat gerusan sejak tahun 2010 saat pertama kali sheetpile dipasang, tetapi penelitian dilakukan sejak tahun 2012 saat terjadi longsoran sampai dengan tahun 2015. Menurut (Fathonah, 2017; Sompie et al., 2018) model Plaxis mampu mengurangi tekanan pasif secara gradual. Menurut (Samia et al., 2017) data kerentanan tanah longsor dapat digunakan sampai 10 tahun.

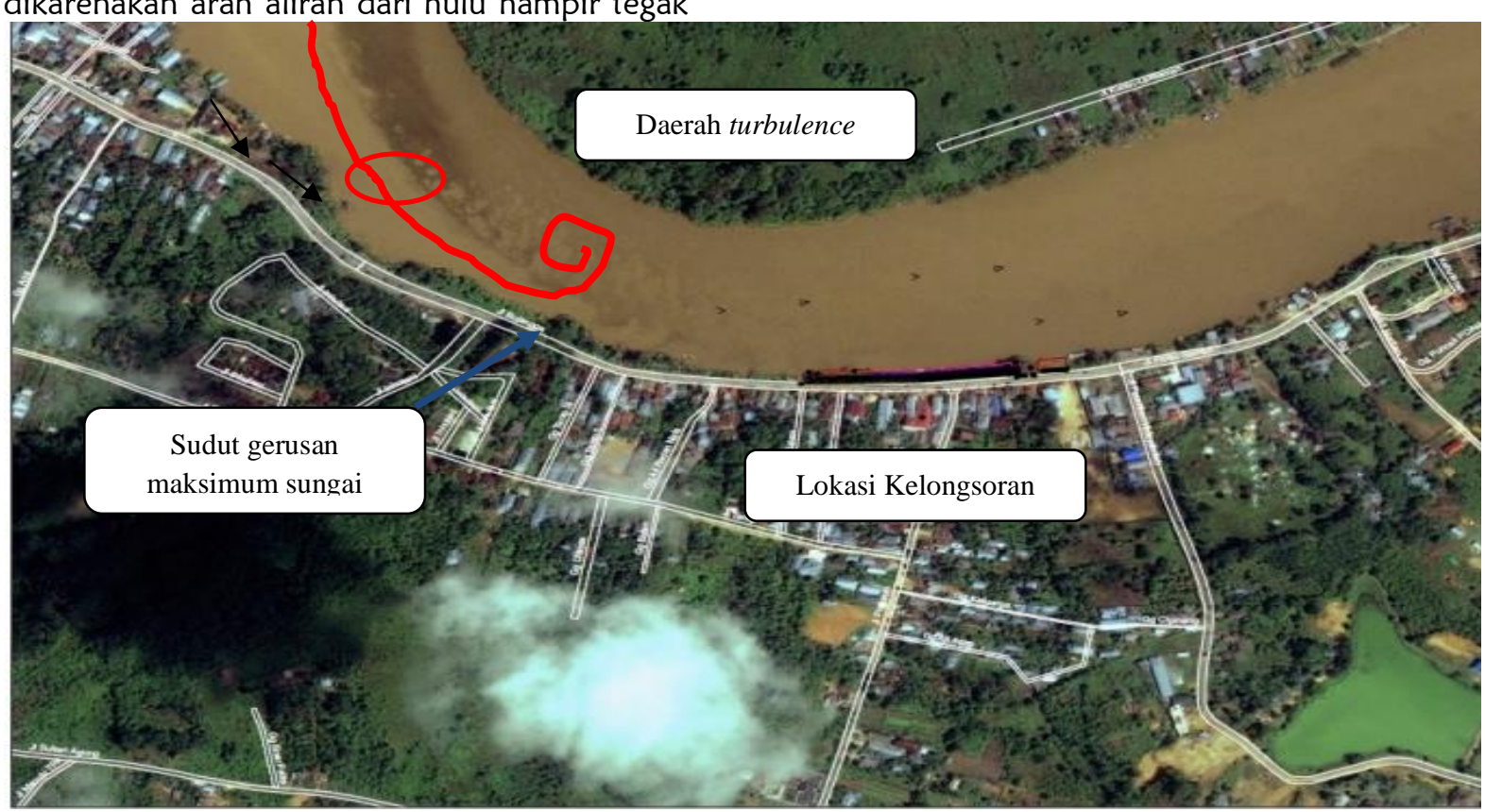

Gambar 4. Posisi Gerusan Akibat Arus Sungai 


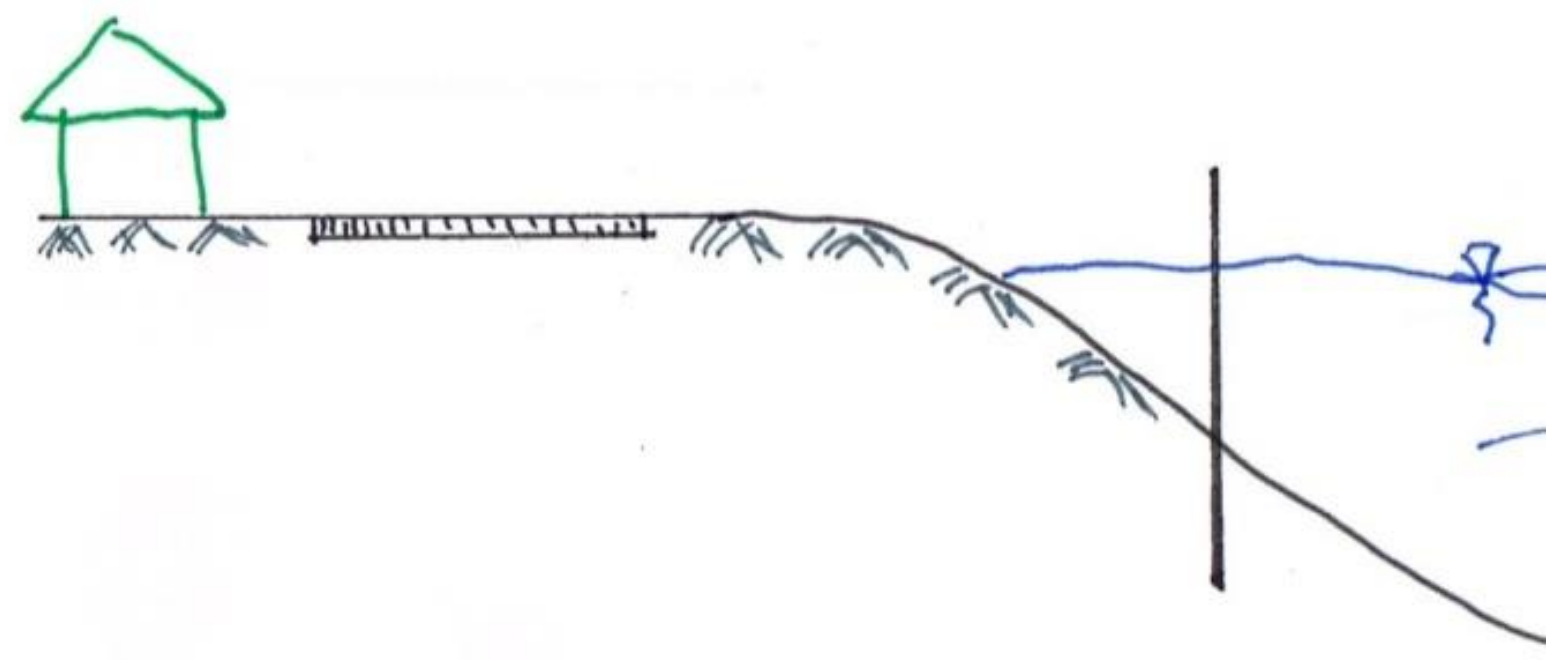

Gambar 5. Ilustrasi Awal Pemancangan Sheetpile Sebelum Ada Gerusan Tahun 2010

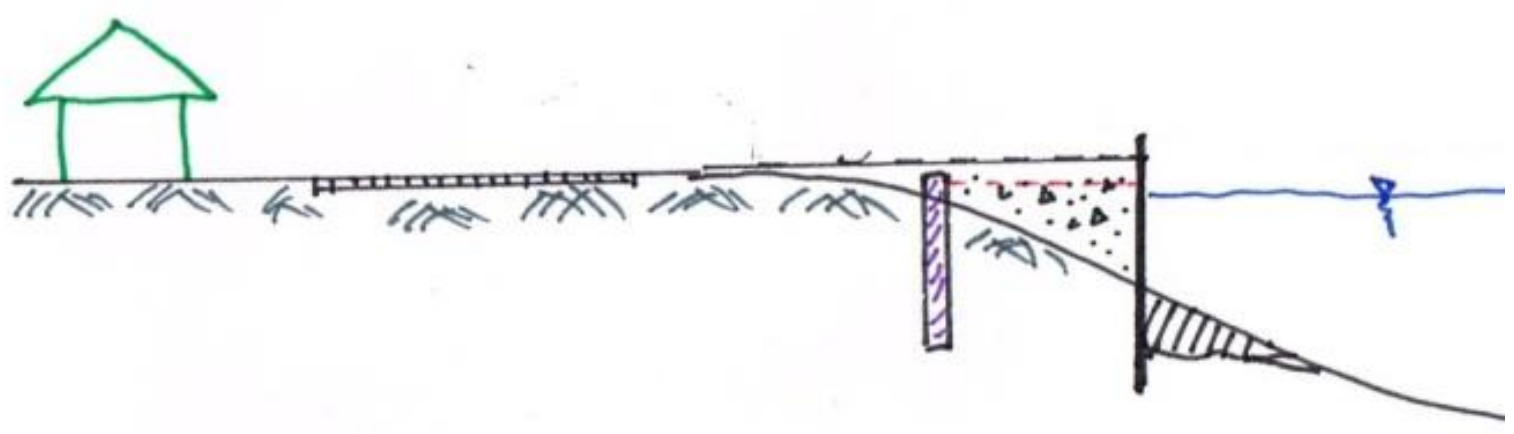

Gambar 6. Ilustrasi Tahap Pengembangan Jalan Setelah Ada Gerusan Tahun 2012

Berikut adalah output analisis stabilitas dengan menggunakan software PLAXIS 2D:

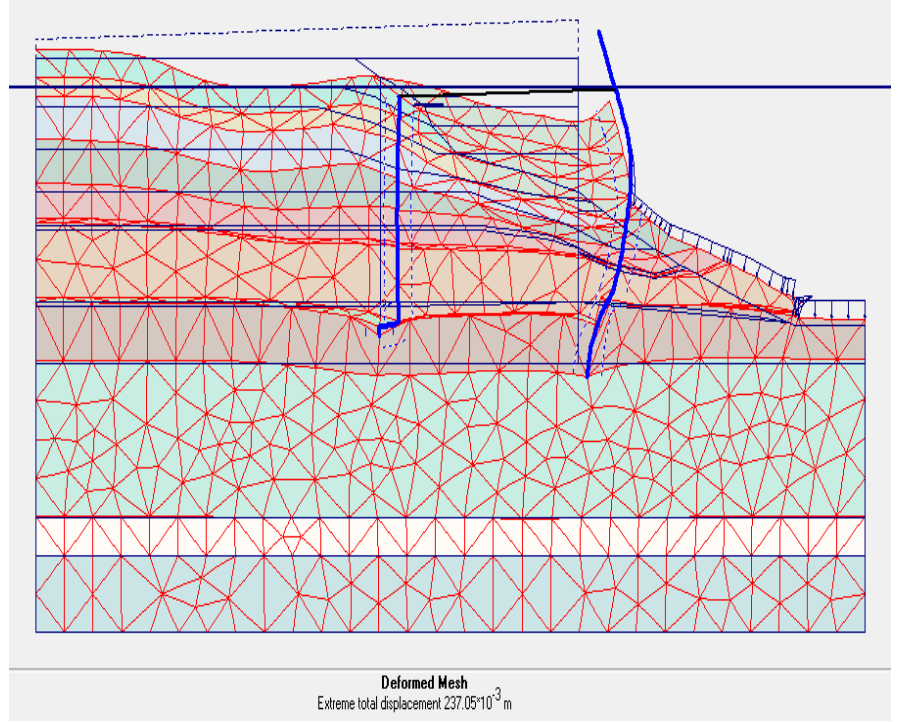

Gambar 7 Deformasi Maksimum Sheetpile (Deformed Mesh) tanpa Simulasi Scouring 


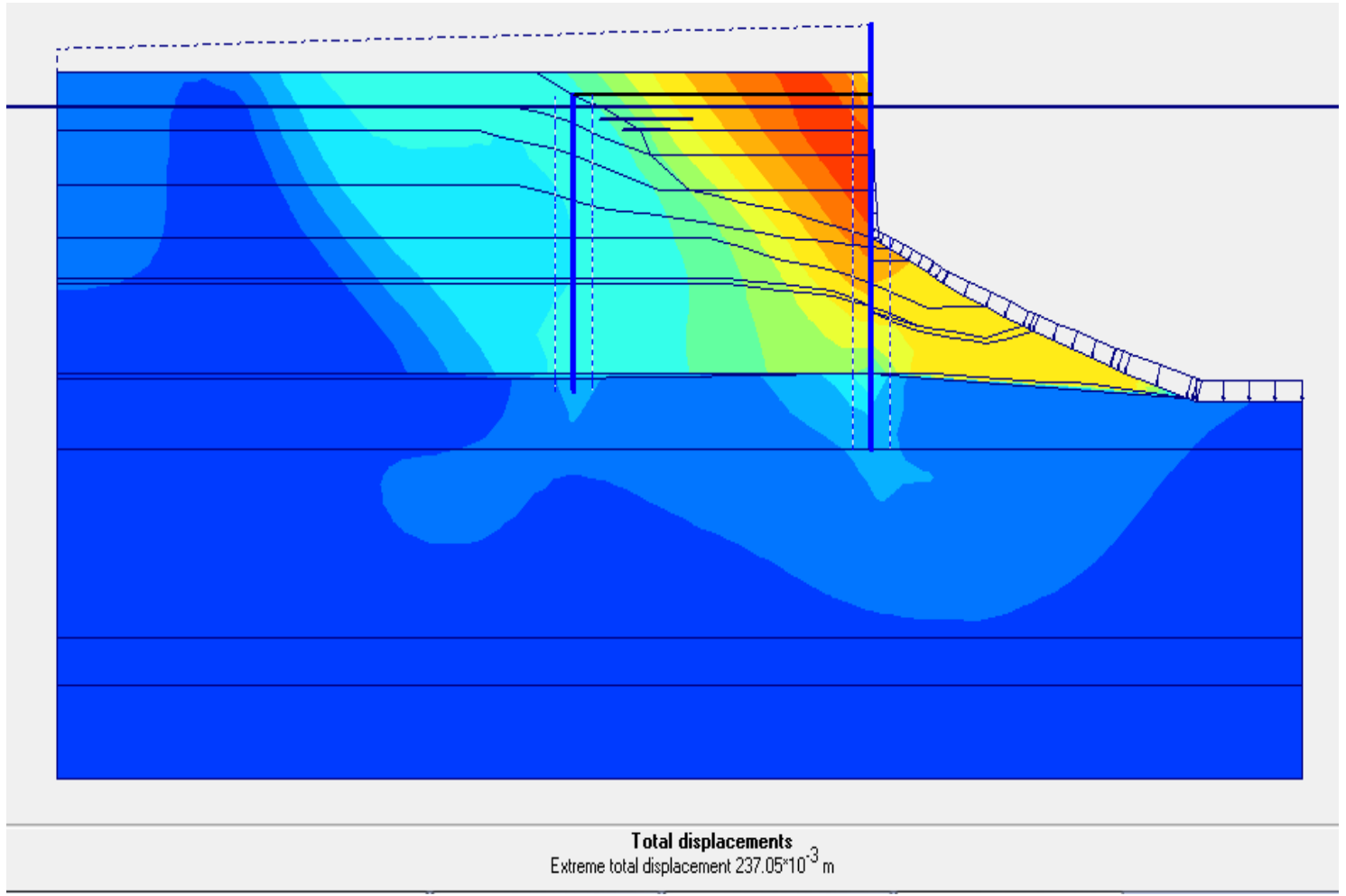

Gambar 8. Deformasi Maksimum Sheetpile (Shading) tanpa Simulasi Scouring

Simulasi analisis stabilitas lereng dilakukan dengan menggunakan metode elemen hingga dengan memperhitungkan dua skenario yaitu tanpa pengaruh scouring dan dengan pengaruh scouring. Dari hasil simulasi tersebut dengan kondisi tanpa pengaruh scouring atau gerusan, nilai stabilitasnya menghasilkan faktor keamanan $\mathrm{FS}=1.2602$ dan deformasi maksimum $23.7 \mathrm{~cm}$.

Dari hasil simulasi dengan memasukkan efek scouring, menunjukkan deformasi maksimum yang dihasilkan pada sheetpile sebesar $1.03 \mathrm{~m}$. Kondisi tersebut sudah termasuk dengan simulasi scouring dengan mengurangi tekanan pasif dibelakang sheetpile. Hasil tersebut tentunya sudah sangat mendekati dengan kondisi lapangan dimana telah terjadi kelongsoran dengan deformasi lateral sebesar $\pm 1.2 \mathrm{~m}$. Hasil tersebut memberikan nilai faktor keamanan sebesar $F S=1.045$, dalam artian jalan tersebut berada pada kondisi sangat labil dan terjadi longsor. Berikut gambar melintang deformasi dengan scouring.

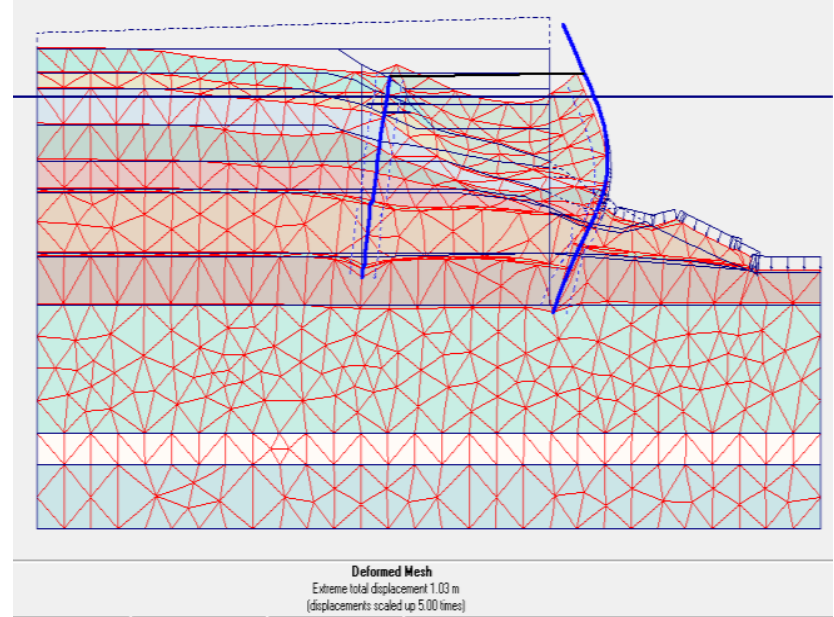

Gambar 9. Deformasi Maksimum Sheetpile (Deformed Mesh) dengan Efek Scouring 


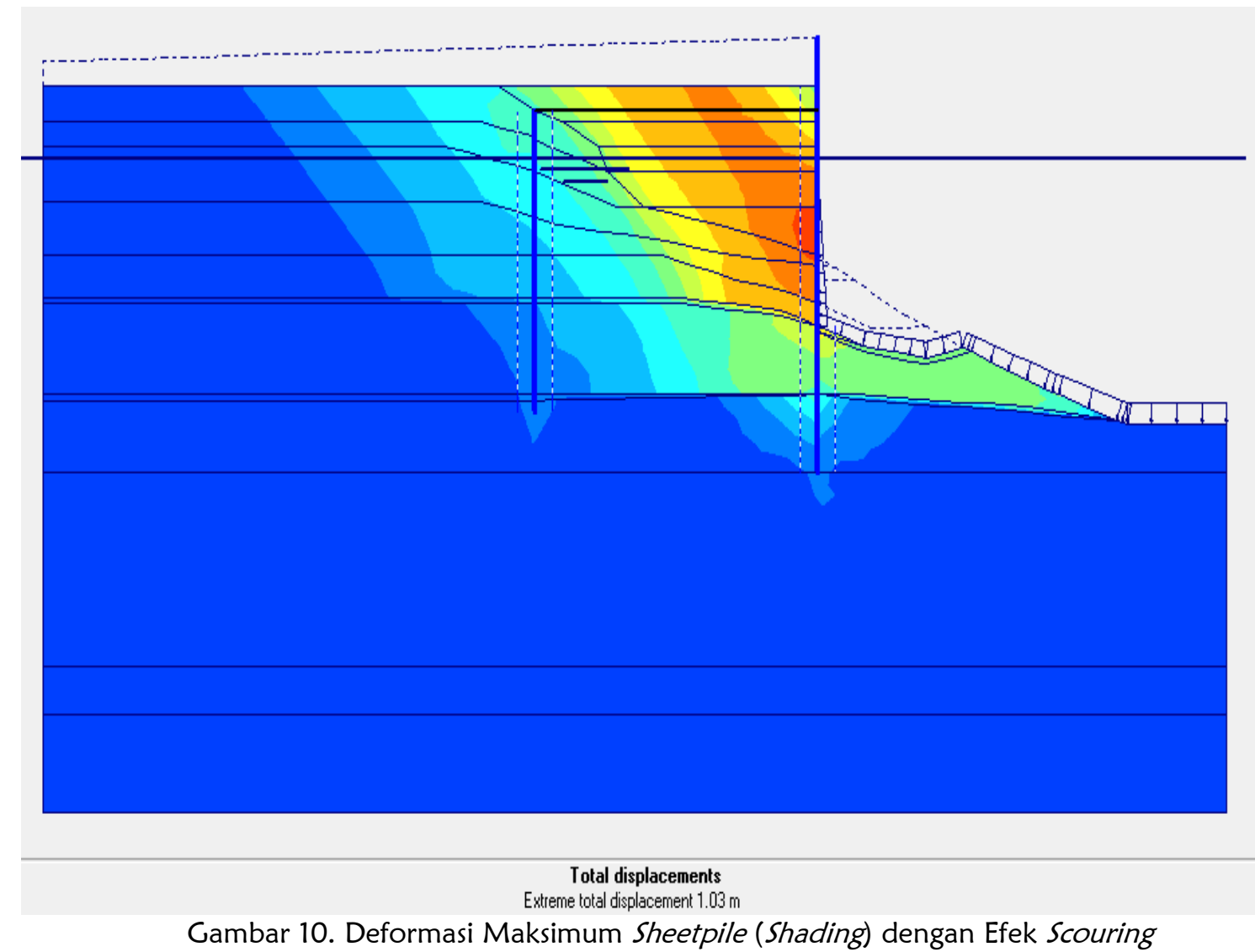

Secara umum perlu kewaspadaan terhadap upaya perkembangan jalan di pinggiran sungai Sengah khususnya jalan Bujangga. Perkembangan jalan memang diperlukan oleh suatu daerah, tetapi perlu juga memilih lokasi yang aman dari longsor baik dari jalan itu sendiri maupun pinggiran sungai. Penghindaran lain juga dari soil creep atau rayapan tanah, supaya infrastruktur yang dibangun tidak miring. Menurut (Rahmad et al., 2018) pinggiran sungai merupakan zona bahaya longsor, sehingga perlu dihindari kegiatan manusia seperti pemukiman dan jalan.

\section{KESIMPULAN}

Longsor disebabkan daerah kelokan sungai Sengah dimana arus sungai hampir tegak lurus menabrak sheetpile. Kedua, turbulensi yang dihasilkan menciptakan arus bawah yang kuat yang dapat menyebabkan gerusan. Akibat dari scouring terjadi pengurangan tekanan pasif pada sisi luar sheetpile yang berakibat pada kerusakan jalan dan pemukiman. Hasil pemodelan dan simulasi menggunakan metode elemen hingga yang memberikan nilai $\mathrm{FS}=1.2602$ tanpa gerusan dan $\mathrm{FS}=1.045$ setelah adanya gerusan. Adanya gerusan pada bibir sungai dapat disimpulkan bahwa dalam skala jangka panjang lokasi tersebut merupakan lokasi rawan bencana longsoran. Rekomendasi dan saran pada penelitian ini bagi pemerintah daerah Kota Tanjung Redep Kabupaten Berau untuk menghindari daerah yang rawan bencana untuk kegiatan manusia seperti pembangunan jalan maupun pemukiman khususnya di Jalan Bujangga pada bagian pinggiran Sungai Sengah.

\section{DAFTAR PUSTAKA}

Amaluddin, L. O., Sejati, A. E., Ihsan, F. A., \& Mutiana, M. (2019). Identification of Huntete beach tourism object in Kulati village East Tomia sub-district Wakatobi regency. Geosfera Indonesia, 3(3), 43-49. https://doi.org/10.19184/geosi.v3i3.8688

Damanik, M. R. S., Nurman, A., Aminy, M. Y., \& Ritonga, I. (2020). Analisis Potensi Longsor Sungai di Daerah Aliran Sungai (DAS) Padang Sumatera Utara. Tunas Geografi, $\quad$ 8(2), 141. https://doi.org/10.24114/tgeo.v8i2.16139

Damhuri, D., Sejati, A. E., \& Hidayati, D. N. (2018). Adaptation of farmers in rice cultivation at dry season in gunungsari village (Bojonegoro-East Java) for learning source. Proceedings of the UR International Conference on Educational Sciences, O(0), 93-99. Retrieved from https://ejournal.unri.ac.id/index.php/ICES /article/view/4737

Fathonah, W. (2017). Analisis Parameter Model 
Tanah Nonlinear Elastoplastic Menggunakan Plaxis 2D Untuk Studi Kasus Galian-Dalam. Jurnal Fondasi, 6(1). https://doi.org/10.36055/jft.v6i1.3166

Kasnar, S., Hasan, M., Arfin, L., \& Sejati, A. E. (2020). Kesesuaian pemetaan daerah potensi rawan banjir metode overlay dengan kondisi sebenarnya di kota kendari. Tunas Geografi, 8(2), 85. https://doi.org/10.24114/tgeo.v8i2.15088

Nursalam, L. O., Arisona, A., Ramli, R., Harudu, L., Kasmiati, S., Harianto, E., Ikhsan, F. A., \& Sejati, A. E. (2019). Mapping of subsurface geological structure and land cover using microgravity techniques for geography and geophysic surveys: A case study of Maluri Park, Malaysia. Geosfera Indonesia, 4(3), 280-290. https://doi.org/10.19184/geosi.v4i3.13738

Pane, R. H. (2017). Faktor penyebab kecenderungam masyarakat memilih tempat tinggal di sempadan sungai padang Kota Tebing Tinggi. Tunas Geografi, 5(1), 33-38. https://doi.org/10.24114/TCEO.V5I1.5852

Rahmad, R., Suib, S., \& Nurman, A. (2018). Aplikasi sig untuk pemetaan tingkat ancaman longsor di Kecamatan Sibolangit, Kabupaten Deli Serdang, Sumatera Utara. Majalah Geografi Indonesia, 32(1), 1. https://doi.org/10.22146/mgi.31882

Samia, J., Temme, A., Bregt, A., Wallinga, J., Guzzetti, F., Ardizzone, F., \& Rossi, M. (2017). Do landslides follow landslides?
Insights in path dependency from a multitemporal landslide inventory. Landslides, 14(2), 547-558. https://doi.org/10.1007/s10346-016-0739$x$

Saragih, A. K., \& Simanungkalit, N. M. (2015). Aktifitas masyarakat dalam pengendalian pencemaran sungai mencirim di Kecamatan Binjai Selatan Kota Binjai. Tunas Geografi, 4(1), 17-26. https://doi.org/10.24114/TGEO.V4I1.5790

Siringoringo, L. F., \& Lumbantoruan, W. (2015). Studi perkembangan prasarana dan sarana transportasi di Kabupaten Samosir sejak tahun 2006-2011. Tunas Geografi, 4(1), 45-50. https://doi.org/10.24114/TGEO.V411.5755

Sompie, G. M. E., Sompie, O. B. A., \& Rondonuwu, S. (2018). Analisis stabilitas tanah dengan model material mohr coulomb dan soft soil. Jurnal Sipil Statik, 6(10), 783-792.

Suparmini, S., Setyawati, S., \& Sumunar, D. R. S. (2014). Mitigasi bencana berbasis kearifan lokal masyarakat baduy. Jurnal Penelitian Humaniora, 19(1). https://journal.uny.ac.id/index.php/huma niora/article/view/3511

Susanti, E., \& Khotimah, N. (2017). Partisipasi masyarakat dalam mitigasi bencana di kawasan rawan bencana iii gunung merapi Desa Mranggen. Geomedia: Majalah Ilmiah Dan Informasi Kegeografian, 14(1). https://doi.org/10.21831/gm.v14i1.13778 
